\title{
OHODNOCENÍ PŘÍNOSU VÝSATBY STROMU゚ PRO ÚZEMNÍ ROZVOJ
}

\author{
EVALUATION OF BENEFITS OF TREE PLANTING IN CONTEXT OF \\ URBAN DEVELOPMENT
}

\begin{abstract}
Svatopluk Pelčák ${ }^{*}, 1$
"pelcak.s@fce.vutbr.cz

${ }^{1}$ Vysoké učení technické v Brně, Fakulta stavební, Veveří 331/95, 60200 Brno

Abstrakt

Se změnou klimatu a rostoucími teplotami, ale také s rostoucími nároky na komfort jednotlivých obyvatel měst, roste také poptávka po co nejpř́ijemnějším prostředí ve městech. Jedním z klíčových prvků pro vytvoření takového životního prostředí je právě strom. Stromy mají řadu dopadů na jejich okolí, at' už jde o dopady pozitivní, tak o dopady, jež zejména komplikují výstavbu technické infrastruktury a vyžadují péči, aby v nepřirozeném městském prostředí prosperovali a tím sloužili svému okolí. Tento výzkum je zaměřen na definování jejich pozitivních dopadů, ale hlavně na jejich ohodnocení tak, aby bylo možné jejich př́nosy porovnat s monetární hodnotou investičních nákladů, ale také k porovnání s jinými monetárně definovanými variantami. Cílem výzkumu je využít tyto hodnoty pro komplexní ohodnocení př́ínosů zeleně pro společnost.
\end{abstract}

\section{Klíčová slova}

Udržitelný rozvoj měst, benefity stromů, socio-ekonomické dopady, vliv zeleně na rozvoj měst.

\section{Abstract}

With climate change and rising temperatures, but also with increasing demand for the comfort of individual citizens, the demand for the most pleasant environment in cities is also growing. One of the key elements for creating such an environment is the tree. Trees have several impacts on their surroundings, both positive and negative impacts, which mainly complicate the construction of technical infrastructure and require care to thrive in an unnatural urban environment and thus serve their surroundings. This research is focused on defining their positive impacts, but mainly on their evaluation so that their benefits can be compared with the monetary value of investment costs, but also to compare with other monetarily defined variants. Goal of the research is to use this values for complex evaluation of its benefits for society.

\section{Key words}

Sustainable urban development, tree benefits, socio-economic impacts, the impact of greenery on urban development.

\section{1 ÚVOD}

Proces městského plánování velkých měst je velkým tématem dnešní doby. S nárůstem migrace lidí do větších měst a jejich širších aglomerací, narůstá také poptávka po bydlení. Tuto poptávku se snaží uspokojit developerské společnosti, které se snaží poskytnout co největší nabídku nových bytů, a tak velmi často staví metodou - co nejvíce obytné plochy na $\mathrm{m} 2$ pozemku. S tímto př́stupem ale souvisí řada problémů pro municipalitu. Rámcově se jedná o zvýšení požadavku na technickou infrastrukturu, zvýšení poptávky po občanské vybavenosti, potřeba veřejného prostoru apod. V takové fázi, kdy už se taková stavba chystá, ale municipalita nemá př́liš velké možnosti zasáhnout do obsahu takového projektu. Protože základním dokumentem, dle jehož se parametry území definují je územní plán a ten je sestaven pro dlouhá časová období.

Doposud se velmi často rozvíjela města mimo své původní hranice. Což vede hlavně k rozrůstání vesnic a menších měst v bezprostředním okolí měst velkých. Tento fenomén je taktéž známý jako tzv. "Urban sprawl", neboli svévolnému rozrůstání měst. Ten má ale za následek velkou řadu negativních dopadů - namátkou jmenujme např́iklad vznikající nefunkční sociální prostředí [1], nepoměrné zatěžování lokální technické infrastruktury, jež 
byla dimenzována na řádově nižší hodnoty, nárůst dílčích cest do zaměstnání (pro soukromá vozidla, ale také veřejnou dopravu), kvalitu života, ale také kvalitu životního prostředí ve městech [2].

Právě kvůli negativním dopadům fenoménu "svévolného rozrůstání měst" se samosprávy zaměřili na budování tzv. měst krátkých vzdáleností. Koncept města krátkých vzdáleností je postavený na promíchaní a vzájemné dostupnosti každodenních potřeb, kterými jsou bydlení, práce, služby, vzdělávání a volnočasové aktivity [3]. Jinými slovy principem je, se v co největší míře stavělo uvnitř stávajících hranic měst a takovým způsobem, aby jednotlivé městské části, čtvrti měli kompletní občanskou, kulturní a veřejnou vybavenost. To ale způsobuje první problém při rozhodování pro rozhodující osoby - a to jaké plochy, v jaké míře by mělo dané území obsahovat. A ačkoliv je pro odborníky možné takovou otázku vyhodnotit, je velmi těžké takováto rozhodnutí kontrolovat, nebo diskutovat, protože se často zakládají na subjektivních hodnoceních. To je dáno charakterem zejména sociálních přínosů budovaných prostranství, jejichž monetární hodnota se jen velmi těžko vyjadřuje. V jiných oblastech (např. doprava) jsou proto využívány tzv. socio-ekonomické dopady, jež jsou právě monetárním vyjádřením sociálních změn způsobených daným projektem.

Proto je také cílem tohoto výzkumu definovat monetární hodnotu přínosu, a to konkrétně pro plochy zeleně ve fázi územního plánování. Hlavním přínosem poté bude, že rozhodující osoby budou mít čísla o která mohou opřít svá rozhodnutí pro rozsah a umístění daného typu ploch.

\section{LITERÁRNÍ PřEHLED/POPIS SOUČASNÉHO STAVU}

Výzkum byl postaven na rozsáhlé rešerši současného stavu, jež měla za cíl nalézt odborné práce, zejména odborníků z oblasti městského rozvoje ale také z oblasti biologie a botaniky, jež mají odborný vhled zvláště do vlastností druhů zeleně.

Výzkum je postaven na rámci práce stanoveném metodicky v přechozím výzkumu. Nejprve bylo v rámci výzkumu nastaveno, které výpočtové metody jsou vhodné pro ohodnocení celospolečenských dopadů velkých projektů územního rozvoje [4]. Následně bylo výzkumem stanoveno, že ideálním zdrojem dat pro hodnocení jsou územní studie. A současně byly parametry území v těchto studiích definovaných rozděleny do kategorií dle jejich přínosu pro území. Jedním z těchto parametrů jsou plochy "městské zeleně". V rámci těchto ploch právě stromy tvoří jeden z nejzásadnějších prvků, jež generují př́nosy pro společnost.

Po rozsáhlé rešerši se podařilo vyhledat klíčový dokument od odborníků ze Spojených států amerických [5]. Tato metodika obsahuje podklady hlavně z pohledu kvantifikace dílčích dopadů, které stromy mohou mít. To zejména jejich vliv na okolní prostředí a z toho i plynoucí dopady na životní prostředí jako celek. Přes značnou snahu autora se nepodařilo nalézt srovnatelnou publikaci, jež by obsahovala, byt' jen výsekovou, část podobných dat a šlo tak ověřit na vyšší úrovni její přesnost. Ale s ohledem na vysokou míru citací této publikaci, a její široké využití ve výzkumu celosvětově, je dostatečně ověřená vědeckou komunitou.

Metodika je konfigurovaná pro rozsáhlé území středozápadu USA, což je oblast, která je vlastnostmi svého klimatu nejblíže středoevropskému počasí. Proto také byla vybrána. Metodika dokonce obsahuje i ohodnocení dílčích dopadů. Jenže také zásadní nedostatek, ceny v publikaci zmiňované odpovídají době před 15 lety, takže cenovou hladinou jsou naprosto neaktuální. Zároveň se jedná o ceny aplikovatelné na území USA a tím pádem se významně liší taktéž cena za jisté komodity.

\section{METODIKA}

Hlavní částí této práce bylo revidovat celospolečenské dopady zeleně, případně je doplnit. A v druhé části popsat a kvantifikovat výši jednotlivého dopadu v kontextu ekonomiky České republiky.

V rámci metodiky jsou stromy pro praktičnost využití rozděleny do 3 kategorií dle velikosti a druhu (na stromy malé, střední a velké). Následně se mění hodnoty se změnou lokality stromů, jestli se nachází u domů, nebo ve volném prostředí. Díky tomuto dělení jsou zdejší výstupy velmi dobře aplikovatelné do různých situací, které nastávají v územním rozvoji. Navíc je publikace rozlišuje ještě na základě stáří. Což opět zpřesňuje výsledky, jelikož u stromů je s jejich rostoucím stářím významná změna zejména v ploše koruny a tím pádem například v ostíněné ploše okolí stromu.

Na základě zmíněné publikace [5], byly převzaty tyto dopady na životní prostředí: Ochlazování okolního prostředí, Oteplení okolního prostředí, Zadržení vody, Pohlcení $\mathrm{CO}_{2}$, Zvýšení kvality ovzduší (pohlcení škodlivin z ovzduší). Aby bylo možno ocenit jednotlivé dopady je nutno zvolit relevantní rámec metodik. Hlavními metodickými přístupy k ocenění jednotlivých dopadů jsou Metody pro netržní oceňování veřejných statků. 


\section{Metody pro netržní oceňování veřejných statků}

V rámci postupu kvantifikace nákladů byla použita ve většině případů kombinace metod nákladů na zamezení, nákladů na nahrazení a nákladů na alternativní opatření.

Metoda ocenění pomocí nákladů na zamezení umožňuje ocenit užitek pomocí nákladů na vyhnutí se škodám, které by mohly vzniknout v případě, že by hodnocený prvek nebyl realizován. Jinými slovy užitek daného prvku je vyčíslen pomocí potenciálních nákladů, kterým se lze vyhnout v př́ípadě, že dojde k jeho realizaci.

Metoda nákladů na nahrazení oceňuje užitky daného objektu podle potenciálních nákladů na nahrazení jejich př́ípadných dopadů jinými prostředky a způsoby.

Metoda nákladů na alternativní opatření vyčísluje užitky daných objektů pomocí nákladů na jiný typ opatření, které by poskytovalo stejné prrínosy. Například lze uvést, že u zelených střech, či stěn lze stejného výsledku ve vztahu k eliminaci škodlivých látek dosáhnout jiným technickým či investičním řešením. Náklady na alternativní řešení se stejným účinkem je v rámci využití této metody možné považovat jako odhad užitků, které poskytuje realizace daného objektu. Není ale vhodné pro toto ocenění využívat jiné prvky zelené infrastruktury, jelikož ty obvykle poskytují také širší spektrum užitků.

\section{Př́nosy výsadby stromů pro společnost}

Jak již bylo zmíněno v rámci literární rešerše, z publikace [4] vychází většina výsledných př́nosů stromů pro společnost. Jejich výčet spolu se stručným popisem metodiky jejich kvalifikace je shrnut v tabulce 1.

Tab. 1 Př́nosy stromů z předchozího výzkumu

\begin{tabular}{|c|c|}
\hline Přínos stromů & Metodika kvalifikace prrínosu \\
\hline $\begin{array}{l}\text { Ochlazování okolního } \\
\text { prostředí }\end{array}$ & Přínos vyjádřen ve formě úspory elektrické energie (kWh). \\
\hline $\begin{array}{l}\text { Oteplení okolního } \\
\text { prostředí }\end{array}$ & $\begin{array}{l}\text { Př́nos vyjádřen ve formě úspory nákladů na zemní plyn pro vytápění } \\
\qquad(\mathrm{MWh}) .\end{array}$ \\
\hline Zadržení vody & $\begin{array}{c}\text { Př́nos vyplývá ze schopnosti stromu zadržovat srážkovou vodu } \\
\text { a snižovat tím zátěž na kanalizací. }\end{array}$ \\
\hline Pohlcení CO2 & $\begin{array}{c}\text { Schopnost stromu pohlcovat CO2 a zároveň snižovat jeho produkci skrze } \\
\text { redukci potřeby elektrické energie. }\end{array}$ \\
\hline $\begin{array}{l}\text { Zvýšení kvality } \\
\text { ovzduší }\end{array}$ & $\begin{array}{c}\text { Schopnost stromu snižováním teploty omezit produkci škodlivých plynů } \\
\text { při výrobě elektrické energie. Zkoumané škodliviny jsou SO2, NOx, } \\
\text { PM10, VOC* }\end{array}$ \\
\hline
\end{tabular}

*VOC = těkavé organické sloučeniny (Zdroj: Vlastní zpracování + data z výzkumu [4],) 


\section{VÝSLEDKY}

V rámci výzkumu bylo dosaženo rozšiření výše zmíněných př́nosů o jeden zásadní a tím je dopad jednotlivých stromů na snížení povrchové teploty komunikací.

\section{Snížení opotřebení komunikací}

Přínos snížení opotřebení komunikací vychází z principu, že stromy snižují razantně povrchovou teplotu povrchu komunikací, která je způsobena jejich vlastnostmi, zejména tmavými odstíny barev, jež z fyzikálního principu pohlcují mnohem více sluneční energie a tím pádem se jejich povrchové teploty, zvláště v letních měsících, dostávají v extrémech i do úrovně kolem $60^{\circ} \mathrm{C}$. Na základě publikace [6] byla zkoumána deformace povrchových vrstev komunikace $\mathrm{v}$ porovnání mezi zatížením komunikace dopravou a zatížením komunikace dopravou za zvýšených povrchových teplot $\left(45^{\circ} \mathrm{C}\right.$ a $\left.55^{\circ} \mathrm{C}\right)$. Na základě této studie z dat bylo evidentní že při teplotě $45^{\circ} \mathrm{C}$ je deformace vozovky trojnásobná oproti zatížení čistě dopravou bez vysokých teplot.

Tento efekt může být do značné míry omezen právě výsadbou stromů u vhodně orientovaných komunikací (ideálně tak aby polední slunce bylo v co největší míře zastíněno právě stromy. Pokud je dosaženo ideálních podmínek a jsou komunikace z velké části ostíněny vysazenými stromy, lze tak redukovat povrchové teploty na komunikacích až o 2,3x - 4,1x oproti stavu komunikací exponovaných přímému slunečnímu svitu. Toto vede k zásadní regulaci opotřebení komunikací a z toho plynoucích nákladů na jejich údržbu. Na základě dat Ministerstva pro místní rozvoj [7] bylo zjištěno že cena vybraných vrstev čtyř pruhové komunikace je $1640 \mathrm{Kč} / \mathrm{m}^{2}$. Tento náklad ovšem je nutno rozložit v čase, aby byl aplikovatelný. Průměrný časový úsek, po kterém je nutné dělat u exponovaných silnic první třídy rekonstrukce povrchu je 8-12 let. Za předpokladu konzervativního přístupu byla využita hodnota 12 let. Z čehož vyplývá náklad $136 \mathrm{Kč} / \mathrm{rok} / \mathrm{m}^{2}$.

\section{Ocenění jednotlivých přínosů výsadby stromů}

V druhé části výzkumu bylo cílem kromě definování dopadů hlavně jejich ocenění a zjištění monetární hodnoty těchto př́nosů. Metody, jak jsou tyto př́nosy definovány jsou shrnuty v tabulce č.1. Metody jejich ocenění jsou vysvětleny následně v tabulce Tab. 2 .

Tab. 2 Principy ocenění jednotlivých př́inosů.

\begin{tabular}{|c|c|}
\hline Přínos stromů & Princip ocenění \\
\hline $\begin{array}{l}\text { Ochlazování okolního } \\
\text { prostředí }\end{array}$ & Měřeno v kWh - Ocenění pomocí tržní ceny elektřiny \\
\hline $\begin{array}{l}\text { Oteplení okolního } \\
\text { prostředí }\end{array}$ & Měřeno v MWh - Oceněn pomocí tržní ceny zemního plynu \\
\hline Zadržení vody & $\begin{array}{c}\text { Měřeno v litrech - Oceněn tržní cenou za stočné, které obsahuje taxu za } \\
\text { údržbu a správu odvodu vod }\end{array}$ \\
\hline Pohlcení CO2 & $\begin{array}{l}\text { Úspora měřena v tunách - Cena stanovena na základě cen za emisní } \\
\text { povolenky pro } \mathrm{CO} 2\end{array}$ \\
\hline $\begin{array}{l}\text { Zvýšení kvality } \\
\text { ovzduší }\end{array}$ & $\begin{array}{l}\text { Úspora měřena v tunách - Cena stanovena na základě studie zdravotních } \\
\text { dopadů škodlivin NHS [8] }\end{array}$ \\
\hline $\begin{array}{l}\text { Snížení opotřebení } \\
\text { komunikací }\end{array}$ & $\begin{array}{c}\text { Měřeno v } \mathrm{m}^{2} \text { zastíněné plochy komunikace - Cena stanovena jako náklad } \\
\text { zamezení škod - cena za opravu povrchu komunikací }\end{array}$ \\
\hline
\end{tabular}

(Z droj: Vlastní zpracování) 
V následující tabulce č.3 jsou popsány jednotlivé hodnoty přínosů rozdělené pro 3 druhy stromů dle velikosti. V této tabulce jsou monetární hodnoty vyjádřené v CZK na jednotku stromu za období jednoho roku.

Tab. 3 Monetární hodnoty př́nosů.

\begin{tabular}{|c|c|c|c|}
\hline \multirow[t]{2}{*}{ Přínos stromů } & \multicolumn{3}{|c|}{ Monetární hodnota přínosu [CZK/rok] } \\
\hline & $\begin{array}{l}\text { Malý strom } \\
\left(32,17 \mathrm{~m}^{2}\right) *\end{array}$ & $\begin{array}{l}\text { Střední strom } \\
\left(53,20 \mathrm{~m}^{2}\right) *\end{array}$ & $\begin{array}{l}\text { Velký strom } \\
\left(99,93 \mathrm{~m}^{2}\right) *\end{array}$ \\
\hline Ochlazování okolního prostředí & 21,62 & 86,49 & 140,54 \\
\hline Oteplení okolního prostředí & 23,57 & 98,90 & 155,29 \\
\hline Zadržení vody & 21,77 & 82,32 & 120,42 \\
\hline Pohlcení CO2 & 21,77 & 82,32 & 120,42 \\
\hline Zvýšení kvality ovzduší & 10,96 & 62,47 & 86,24 \\
\hline \multicolumn{4}{|l|}{$\begin{array}{c}\text { Snížení opotřebení komunikací (jen } \\
\text { u stromů u komunikací) }\end{array}$} \\
\hline & 1312,55 & 2170,56 & 4077,14 \\
\hline
\end{tabular}

*Půdorysná plocha koruny (Zdroj: Vlastní zpracování)

\section{DISKUZE}

Ve výzkumu bylo dosaženo výstupů, které byly cílem výzkumu. Byla rozšířena řada dopadi̊, jež byly zjistitelné z literatury, o př́nos snižení opotřebení komunikací. Následně bylo dosaženo hlavního cíle a tím bylo stanovit dílčí přínos za výsadbu jednoho stromu. Tyto dopady byly rozděleny do 3 kategorií dle velikost stromu. Tyto velikosti odpovídají vzrůstu po 5 letech od zasazení.

Hodnoty popsané v tabulce 3 popisují hodnoty ročního př́nosu stromu v CZK. Tyto výsledky lze využít k použití v kontextu širších dopadů např́iklad do CBA analýzy, kde lze tyto hodnoty postavit proti investičním nákladům na realizaci daných úprav území.

Jisté omezení má nově definovaný přínos "Snížení opotřebení komunikací". Ten lze použít pouze za předpokladu že je v bezprostřední blízkosti exponované komunikace, na které lze pozorovat úspory z údržby.

Stojí za zvážení, zdali by nebylo vhodné dále pracovat na rozšíření těchto dopadů tak, aby byla i jejich monetární hodnota vyšší. Protože v současnosti se tyto hodnoty u jednotek stromů pohybují v úrovni desítek korun za rok, což je velmi nízká hodnota přínosu. 


\section{ZÁV̌̌R}

V rámci výzkumné práce byl největší objem práce investován do zkoumání jednotlivých př́stupů na co nejvhodnější ocenění a př́ípadnou kvalifikaci dalších přínosů. Bylo dosaženo rozšíření základních přínosů o přínos "Snížení opotřebení komunikací". Dále byly stanoveny hodnoty jednotlivých přínosů v CZK/rok. Jednotlivé hodnoty jsou relativně nízké proto bude vhodné $\mathrm{v}$ následujícím výzkumu přistoupit $\mathrm{k}$ rozšíření dopadů jednotlivých parametrů tak, aby se jejich hodnoty zvýšili. To je důležité proto, aby bylo možné je postavit proti nákladům na realizaci. Toto téma není frekventovaně řešeným tématem, proto je těžké je s jinými výzkumy porovnávat. Velmi často výzkumy končí ve fázi kvalifikace jednotlivých př́inosů, ale nevěnují se jejich ocenění.

Tato práce dle pohledu autora zásadně posouvá oblast ocenění socio-ekonomický dopadů v kontextu územního rozvoje. Další práce bude zaměřena zejména na dokončení ohodnocení ploch zeleně. A následně pokračovat na ohodnocování dalších dopadů rozvoje území. Práce je součástí disertačního výzkumu, jež má za cíl definovat co nejvíce relevantních socio-ekonomických dopadů rozvoje území. V tomto duchu se bude rozvíjet i následující výzkum.

\section{Poděkování}

Tento článek byl zpracován v rámci projektu specifického výzkumu VUT v Brně č. FAST-J-21-7448 (Socioekonomické dopady projektů rozvoje území a jejich zasazení do kontextu územního rozvoje).

\section{Použité zdroje}

[1] Jan K. Brueckner, Ann G. Largey,Social interaction and urban sprawl,Journal of Urban Economics, Volume 64, Issue 1,2008,Pages 18-34, ISSN 0094-1190, https://doi.org/10.1016/j.jue.2007.08.002.

[2] Burchell, R. W. (2002). Costs of sprawl--2000. Transportation Research Board.

[3] NOVOTNÝ, Tomáš. Koncept města krátkých vzdáleností [online]. Praha, 2019 [cit. 2021-11-09]. Dostupné z: https://theses.cz/id/xehunq/. Diplomová práce. Vysoká škola ekonomická v Praze. Vedoucí práce Jiří Patočka.

[4] PELČÁK, Svatopluk a Jana KORYTÁROVÁ. Selection of the Best Option of Brownfield Revitalization Using the Habu Method. In: IOP Conference Series: Materials Science and Engineering [online]. IOP Publishing, 2020, s. 1-7 [cit. 2021-11-12]. ISSN 1757-8981. Dostupné z: doi:10.1088/1757899X/960/4/042108

[5] McPherson, E. G., Simpson, J. R., Peper, P. J., Maco, S. E., Gardner, S. L., Cozad, S. K., \& Xiao, Q. (2006). Midwest community tree guide: benefits, costs, and strategic planting. U.S. Department of Agriculture, Forest Service, Pacific Southwest Research Station. https://doi.org/10.2737/psw-gtr-199

[6] Alkaissi, Z. A. (2020). Effect of high temperature and traffic loading on rutting performance of flexible pavement. In Journal of King Saud University - Engineering Sciences (Vol. 32, Issue 1, pp. 1-4). Elsevier BV. https://doi.org/10.1016/j.jksues.2018.04.005

[7] MMR -Průměrné ceny dopravní a technické infrastruktury[online]. Copyright (C) [cit. 12.11.2021]. Dostupné z: https:/www.mmr.cz/getmedia/695b35fe-4e46-4550-99086e5709b35d72/2016_V_09_prumerne-ceny-di-a-ti.pdf?ext=.pdf

[8] Air Quality damage cost update 2019 [online]. Copyright (C) [cit. 12.11.2021]. Dostupné z: https://ukair.defra.gov.uk/assets/documents/reports/cat09/1902271109_Damage_cost_update_2018_FINAL_Iss ue_2_publication.pdf 